\title{
A Significant Range Extension for the Eastern Ribbonsnake, Thamnophis sauritus, in Nova Scotia, Canada
}

\author{
John Gilhen $^{1}$, Alice Jones ${ }^{2}$, JefFie McNeIL ${ }^{3}$, and Arthur W. TANner ${ }^{4}$
}

${ }^{1}$ Nova Scotia Museum of Natural History, 1747 Summer Street, Halifax, Nova Scotia B3H 3A6 Canada; email: gilhenja@gov .ns.ca

${ }^{2} 586$ Crouse Settlement Road, Italy Cross, Lunenburg County, Nova Scotia B4V 0P8 Canada

${ }^{3}$ Mersey Tobeatic Research Institute, 9 Mount Merrit Road, P.O. Box 215 Kempt, Queens County, Nova Scotia B0T 1B0 Canada

${ }^{4} 91$ Fitch Road, Conquerall Mills, Lunenburg County, Nova Scotia B4V 6E3 Canada

Gilhen, John, Alice Jones, Jeffie McNeil, and Arthur W. Tanner. 2012. A significant range extension for the Eastern Ribbonsnake, Thamnophis sauritus, in Nova Scotia, Canada. Canadian Field-Naturalist 126(3): 231-233.

In Nova Scotia the threatened Northern Ribbonsnake, Thamnophis sauritus septentrionalis, (the northern subspecies of the Eastern Ribbonsnake, T. sauritus) (Crother 2008) is known from localities in only Queens and Lunenburg counties, where it was first discovered in 1950. Many new localities, mostly in the headwaters of the Mersey River and the Medway River watersheds have been added since 2002, and Seven Mile Lake (in the West La Have River watershed) was added to the distribution in 2005. We add two localities to the distribution of the Northern Ribbonsnake in the previously unreported Petite Rivière watershed, Lunenburg County, Nova Scotia.

Key Words: Northern Ribbonsnake, Thamnophis sauritius septentrionalis, Eastern Ribbonsnake, Thamnophis sauritus, species at risk, new localities, Minamkeak Lake, Mud (Snake) Lake, Italy Cross, Petite Rivière watershed, Nova Scotia.

On 15 August 2011 one adult Eastern Ribbonsnake, Thamnophis sauritus, was observed and photographed by Arthur Tanner at Minamkeak Lake, Lunenburg County, Nova Scotia (approximately $44^{\circ} 17^{\prime} 19.82^{\prime \prime N}$, 64³8'39.89"W) (Figure 1). On the 18 January 2012 another adult was discovered by Alice Jones near Mud (Snake) Lake, Italy Cross, Lunenburg County, Nova
Scotia $\left(44^{\circ} 16.256^{\prime} \mathrm{N}, 64^{\circ} 33.299^{\prime} \mathrm{W}\right)$. A picture was taken by cell phone and is on file at the Nova Scotia Museum of Natural History. Both localities are within the Petite Rivière watershed, which has been added to the range of the Eastern Ribbonsnake in Nova Scotia (Figure 2). The Italy Cross record represents the only January sighting of the Eastern Ribbonsnake in Nova Scotia.

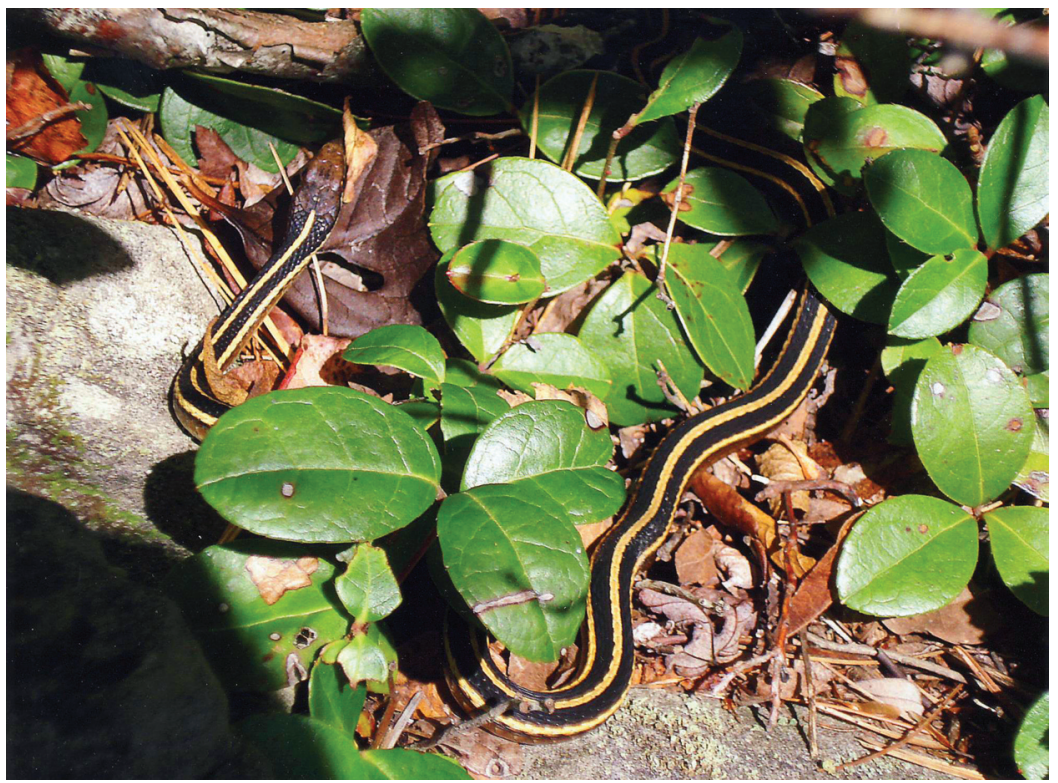

FIGURE 1. Northern Ribbonsnake, Thamnophis sauritus septentrionalis, from Minamkeak Lake, Lunenburg County, Nova Scotia.15 August 2011. Photo Arthur Tanner. 


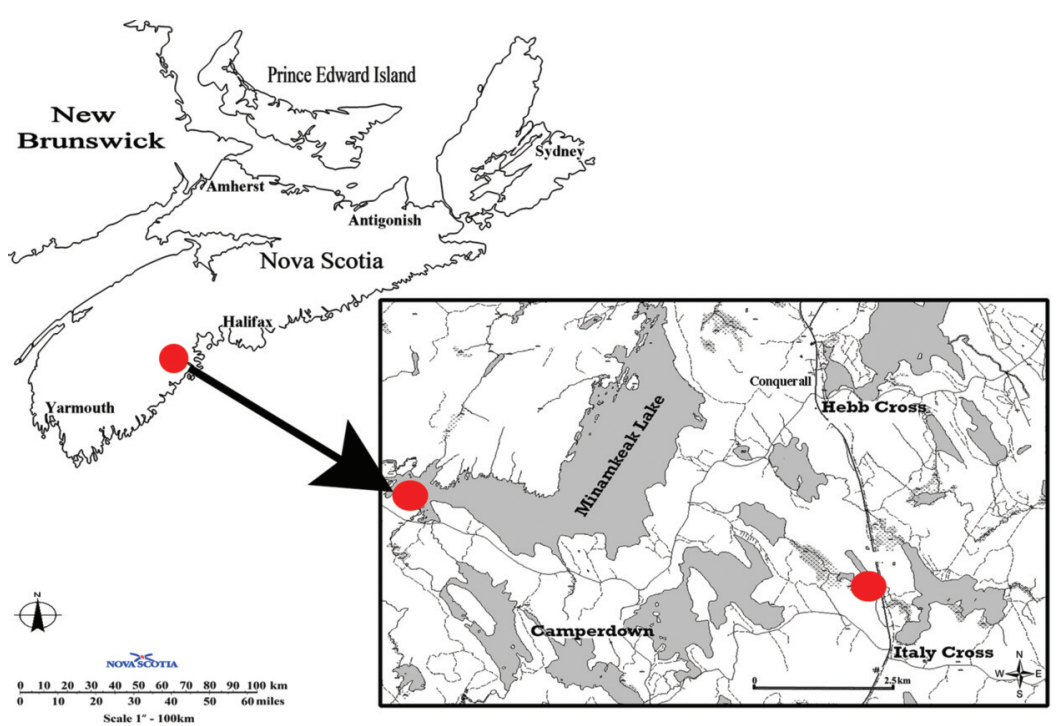

FIGURE 2. Distribution of the Northern Ribbonsnake, Thamnophis sauritus septentrionalis, in the Petite Rivière watershed, Lunenburg County, Nova Scotia.

This location is approximately $35 \mathrm{~km}$ south east of Seven Mile Lake, the nearest previously recorded Eastern Ribbonsnake location.

\section{Discussion}

The Eastern Ribbonsnake, Thamnophis sauritus, is a complex of four subspecies widespread in eastern North America (Ernst and Ernst 2003). Canadian populations are represented by the Northern Ribbonsnake, Thamnophis sauritus septentrionalis (Cook 1984; Gilhen 1984). The Northern Ribbonsnake is a slender satiny black snake with yellow dorsal and lateral stripes. It has a caramel brown stripe below the yellow lateral stripes, and it always has yellowish white pre-ocular scales.

The Thamnophis sauritus septentrionalis was unknown in Nova Scotia until 12 July 1950 when an adult male and a female were discovered at a bog pond near Kempt, Queens County, in the Medway River watershed (Bleakney 1951). Later the same day another adult female was found at Caledonia, Queens County, and a third adult female was taken at Kempt on 20 July 1950 (Bleakney 1951). Over the next 50 years very few Northern Ribbonsnakes were recorded and almost all of those were within the headwaters of the Mersey River and the Medway River watersheds.

The Atlantic population of the Eastern Ribbonsnake was designated as threatened by the Committee on the Status of Wildlife in Canada in May 2002 (COSEWIC 2002), and subsequently was listed under the Nova Scotia Endangered Species Act. The Eastern Ribbonsnake Recovery Team was established in 2003.
Like the Blanding's Turtle, Emdoidea blandingii, the Northern Ribbonsnake is a climatic relict from the warm Hypsithermal period, of 3000 to 5000 years before present (Parks Canada Agency 2012) (see Bleakney 1958; Cook 1984; Gilhen 1984). During the Hypsithermal the range of the Eastern Ribbonsnake is thought to have been continuous throughout New Brunswick and the northeastern United States. Today in the Maritimes, the Northern Ribbonsnake is found in only southwestern Nova Scotia, the warmest region in the Maritimes (Bleakney 1958; Cook 1984; Gilhen 1984).

The principal objectives of the Eastern Ribbonsnake Recovery Team have been to determine the extent of the distribution in Nova Scotia and to estimate the population size (Parks Canada Agency 2012. Through the field efforts of volunteers and the recovery team (over a dozen individuals), new localities have been discovered, mostly in the headwaters of the Mersey River and the Medway River watersheds. On 13 July 1995 Seven Mile Lake, in the western LaHave River watershed, was included. Reports from East Lake, Annapolis River watershed, are currently being investigated (Eastern Ribbonsnake Recovery Team. 2012. Nova Scotia Ribbonsnake Database accessed 20 February 2012).

The earliest appearance in spring and latest observation in autumn of most species of amphibians and reptiles in Nova Scotia listed by Gilhen (1984) have been recorded by numerous individuals. Alice Jones' observation of an Eastern Ribbonsnake on 18 January 2012 is the only winter record for the Eastern Rib- 
bonsnake and is probably linked to climate change. The snake was active on the woods road near Mud Lake and Edward Himmelman, owner of the property at Italy Cross, mentioned the air temperature was about $10^{\circ} \mathrm{C}$, warm enough to work in the woods in short sleeves.

\section{Acknowledgements}

The authors are grateful to Andrew Hebda, Curator of Zoology, Nova Scotia Museum of Natural History, for valuable comments and suggestions. The distribution map was prepared by Roger Lloyd, Collections Unit of the Nova Scotia Museum. We are grateful to Randall Himmelman for his assistance in the field and to his brother, Edward Himmelman for permission to investigate the observation site on his property at Italy Cross.

\section{Documents Cited (marked $*$ in text)}

Committee on the Status of Endangered Wildlife in Canada (COSEWIC). 2002. COSEWIC assessment and status report on the eastern ribbonsnake, Thamnophis sauritus. Committee on the Status of Endangered Wildlife in Canada, Ottawa, Ontario.

Scientific and Standard English names of amphibians and reptiles of North America north of Mexico, with comments regarding confidence in our understanding. Com- mittee on Standard English and Scientific Names. Sixth Edition. Edited by Brian I. Crother. 2008. Society for the study of amphibians and reptiles Herpetological Circular 37. 84 pages.

Parks Canada Agency. 2012. Recovery strategy for the Eastern Ribbonsnake (Thamnophis sauritus) Atlantic population in Canada. Species at Risk Act Recovery Strategy Series. Parks Canada Agency, Ottawa, Ontario. X + 46 pages.

\section{Literature Cited}

Bleakney, J. S. 1951. A new snake record for Nova Scotia. Canadian Field-Naturalist (65): 118-119.

Bleakney, J. S. 1958. A zoogeographical study of the amphibians and reptiles of eastern Canada. National Museums of Canada. Bulletin 155.

Cook, F. R. 1984. Introduction to Canadian Amphibians and Reptiles. National Museum of Natural Sciences, National Museums of Canada. Ottawa, Ontario.

Ernst, H., and E. M. Ernst. 2003. Snakes of the United States and Canada. Smithsonian Books, Washington and London. 668 pages.

Gilhen, J. 1984. Amphibians and Reptiles of Nova Scotia. Nova Scotia Museum. Halifax, Nova Scotia.

Received 24 May 2012

Accepted 26 September, 2012 